Article

\title{
The Transition to Renewable Energy Technologies-Impact on Economic Performance of North Rhine-Westphalia
}

\author{
Gianmarco Aniello ${ }^{1, *(\mathbb{D})}$, Johannes Többen ${ }^{2}$ and Wilhelm Kuckshinrichs ${ }^{1}$ (]) \\ 1 Institute of Energy and Climate Research-Systems Analysis and Technology Evaluation (IEK-STE), \\ Forschungszentrum Jülich, 52425 Jülich, Germany \\ 2 Industrial Ecology Program (IndEcol), Department of Energy and Process Engineering, \\ Norwegian University of Science and Technology (NTNU), 7034 Trondheim, Norway \\ * Correspondence: g.aniello@fz-juelich.de
}

Received: 16 July 2019; Accepted: 5 September 2019; Published: 10 September 2019

\begin{abstract}
The economic impacts of the German Renewable Energy Act (EEG) are of considerable importance for the discussion of the energy transition in Germany (Energiewende). The Energiewende implies structural changes of the energy system by deploying Renewable Energy (and energy efficiency) Technologies (RET), but it also may induce structural changes for the overall economy, with uneven effects on a sub-national level. North-Rhine Westphalia (NRW) is an ideal case to study such regional disparities, since this federal state has scarce per-capita renewable energy sources, whereas it stands out for its energy intensive industry and fossil-fuel based power plants. In order to support renewable energy policies, mostly gross impact assessments of RET deployment have been carried out both on national and regional levels. By definition, such analyses result in positive assessments, since only expansionary effects resulting from additional demand for RET are accounted for. This paper, in contrast, presents a net impact assessment of the EEG on the NRW economy of both expansionary and contractionary effects. The latter consist of negative income effects, increased production costs and, the crowding-out of conventional energy due to the renewable energy financing mechanism (i.e., electricity surcharge), as well as its preferential status for feed-in. Our findings show how North-Rhine Westphalia, with regard to the operation of RET, suffers disproportionally from negative effects in relation to the value addition of its economy in comparison to the rest the country, whereas it benefits marginally from the production of such facilities.
\end{abstract}

Keywords: Renewable Energy Act; value added; regional analysis; North Rhine-Westphalia; input-output model

\section{Introduction}

The economic effects of support schemes for renewable technologies and respective deployment of technologies are of considerable importance worldwide [1-3]. This also holds for Germany and the Renewable Energy Act (Erneuerbare-Energien-Gesetz, EEG) as a prominent example for a financial support instrument. The EEG promotes the feed-in of electricity from renewable energy sources and comprises two basic principles: it guarantees producers a fixed feed-in tariff (FiT) and also gives preference to electricity from renewable energy sources being fed into the German power grid over electricity from conventional sources. It is financed by a surcharge levied on electricity consumers, namely the EEG-Umlage. However, this is a controversial topic in the public debate on the transformation of the German energy sector (Energiewende) [4-9]. The controversy focuses both on the general economic efficiency of the $E E G$ and the regional divergence of economic impacts. Some regions 
are concerned about socio-economic impacts in the course of the Energiewende and value added impacts of the EEG. This is the most significant aspect for North Rhine-Westphalia (NRW), the most populous federal state in Germany with a strong energy-industrial basis (domestic coal mining, fossil-based power plants) and home to important industries (car manufacturing, mechanical engineering, as well as energy-intensive industries such as metal production and chemistry), while suffering from comparably poor socio-economic trends (e.g., GDP growth, tax base).

This paper analyses the socio-economic effects of the EEG in NRW and Germany, focusing on value added generation. As the year 2011 documented a surge in renewable energy technology investments in Germany, particularly in photovoltaics, this year is taken as an example. The analysis will consider the direct influences of the operation and production of renewable energy facilities in NRW itself, as well as the indirect effects of production and operation in the other federal states. These indirect effects concern, for example, households and companies in NRW who have to pay an EEG levy or by the manufacturers of wind turbines obtaining intermediate goods (e.g., steel or gears) from NRW. The remainder of this paper is structured as follows: Section 2 focuses on methodological aspects, presents a literature survey and the approach chosen for the NRW study. Section 3 analyzes the mechanisms of the EEG and presents structural data for NRW. Section 4 describes briefly the model and data used, as well as the EEG-based investment and operation impact channels relevant for NRW and Germany. The results of the analysis are presented in Section 5, demonstrating valued added impacts for NRW and for Germany. In Section 6 central assumptions and their relevance for results are discussed, and conclusions are drawn.

\section{Literature Review}

Several approaches have been implemented, in order to evaluate the impact of the deployment of renewable energies on employment, value added and/or GDP. Breitschopf et al. [2] provide an overview of the methods used in the literature. Impact assessments can be distinguished in two broad categories: gross impact studies and net impact ones. The first type simply aims at assessing how many jobs (or value added) are created as result of activities along the value chain of RE (renewable energy) generation. By definition, gross impact studies result in an expansionary outcome of RE. On the other hand, if households and enterprises finance RET promotion (e.g., through higher energy prices), this will result in a lower disposable income and higher production costs; therefore, contractionary effects will spread throughout the economy. Net impact studies should ideally take into account all sorts of direct, indirect, and induced effects (see [2]) for a detailed description of all potential effects), and possibly compare multiple scenarios of RET deployment. Nevertheless, net impact studies differ greatly in the scope of the effects considered; in fact, the outcomes of RET deployment are very complex and cannot be easily fully encompassed within one study.

The particular focus on the time horizon (past, present, future), the aggregation level (sub-national, national, supranational), and the kind of impact indicator (quantity/quality of employment, value added, GDP) may shape the methodology as well. For the sake of brevity, we group methodologies into three main categories: (1) Employment factors and Value Chain Analysis, (2) Cost-based input-output (I-O) modelling, and (3) Full economic assessment (or complex macroeconomic modelling).

The employment factors approach has been widely applied in the literature, since it is the simplest analytical approach. "Green" jobs are estimated by multiplying the installed capacity or energy generation by employment factors (e.g., jobs per MW of capacity), specific for each life cycle phase activity (direct jobs generation) and its supply chain (indirect jobs generation) of a given RE (renewable energy) technology. Cameron and Van Der Zwaan [3] carry out a systematic review of the employment factors present in the literature, finding that the bulk of the studies does not estimate original coefficients, but takes them from the literature itself. On the other hand, original estimates show large differences across studies (up to 10-folds). RE jobs creation can sometimes be compared with CE (Conventional Energy) jobs reduction, so that some negative impact can be accounted for. The value chain approach, similar to employment factors, focuses on life cycle phases, and analyzes different components and/or 
stages within the same phase. For both approaches, a system boundary must be defined. Whereas the first approach accounts merely for job unities, the second one can account for all value added attributable to RE (labor, profit, taxes).

The cost-based I-O approach can account for all direct and indirect impacts ("ripple effect") across all upstream industries, since there is no system boundary other than the economic system. A major limitation of this approach is that I-O sectors are assumed to be proxies of RE-related activities. Business surveys can help circumvent such limitations: data on cost structures of intermediates, import shares and labor coefficients can be combined with official statistics sectoral disaggregation. Blyth et al. [1] distinguish two sub-approaches to integrating RE technology-specific data: either each expenditure from RE activities is assigned to the existing I-O sectors, or a new RE sector can be created, with full forward and backward linkages. A second weakness is that standard I-O models are demand-driven, and therefore an increased exogenous demand in RE will result in a corresponding adjustment of the supply. That is, neither supply maximum capacity (capital/labor fixed supply) nor resources sectoral shift are considered. Thirdly, if total demand is considered exogenous, neither the budget effect due to energy surcharges nor the increased consumption from households (due to RE labor income) will be considered (i.e., induced effects). Applying such standard demand-driven I-O model results in a gross impact study. However, a series of adjustments can be applied to overcome such limitations. Firstly, the model can be "closed" with respect to households so that additional labor income can be re-spent by consumers [10]. Secondly, price effects can be accounted by integrating it in an average consumption vector. Finally, negative changes in crowded-out sectors can also be included in this framework. A sophisticated cost-based IO model that includes such adjustments is implemented in this study (see Section 4). This approach has been firstly applied by Többen [8].

The full economic assessment is a complex approach that can involve macroeconomic, trade, and energy modules and the application of macro-econometric or CGE (Computable General Equilibrium) modelling. These kinds of studies can aim at assessing all direct, indirect, and induced effects, including, for example, substitution effects in consumption and production due to changes in relative prices. They usually involve the simulation of alternative future scenarios, whose comparison represents a net impact. This complexity requires a large amount of data and assumed parameters (e.g., elasticities), and thus the quality of results hinges crucially on these. Breitschopf et al. [2] conclude that the full economic assessment approach is, theoretically, the most scientifically accurate and comprehensive, however, in practice, it is often not very feasible.

The impact of EEG in Germany has been extensively analyzed in the literature. Net impact studies, which focused on the national level, have had contrasting results, leading to both negative assessments (e.g., [11-14] and positive ones (e.g., $[6,15,16])$. Others have criticized the widespread optimism concerning the economic impact of $E E G$ and highlight the increasing burden on consumers and the inefficiency in reducing $\mathrm{CO}_{2}$ emissions [5,17]. Böhringer et al. [18], by applying a Computable General Equilibrium (CGE) model, find that promotion of renewable energy through surcharge may have minor benefits only when subsidies are low, otherwise significant welfare losses are generated. Böhringer et al. [19] propose the financing of FiTs through uniformly increased VAT (value added tax) on all consumption goods, since such an alternative financing mechanism would reduce the macroeconomic costs of $E E G$ and also the regressive effect on poorer households [20]. Lehr et al. [6] notice that the assumptions about international trade of RE technologies are the main drivers for such diverging results in the literature on the German case. In fact, when a low export scenario (a detailed description of international trade scenarios is given in Lehr et al. [15] where projections are based on surveyed market shares of 2007) is assumed, they even find a negative net impact. Meyer and Sommer [21] review several net employment effect studies, concluding that these are hardly comparable because of the complexity of their set of assumptions, methodologies, system boundaries, and policy scenarios. In particular, for the outcome of such analyses, they highlight the importance of dynamism of the RET sector (w.r.t. import and export structures, technological development), as well as the effects of the financing mechanism. 
The relevance of international trade in estimating the impact of RE deployment at the country level, has been investigated outside the German context as well. Cai et al. [22] find that each euro invested in the RE sector, generated between 31 to $41 \%$ less value added in the Italian economy, compared to an average bundle of investment goods and services, because of the high reliance on imports for the RE sector. Similarly, Ortega et al. [23] focus on the role of international trade of RE technologies, and distinguish between importer and exporter EU members in order to estimate country-specific employment factors of RE deployment. Accounting for international trade of RET is not a straightforward task, given the lack of official trade statistics for a "RE" sector.

If the scope of the study is the analysis of the regional/local impact of RET deployment, even intra-national trade data are needed. Gross impact assessments of wind energy deployment have been conducted in the U.S at the state level for Nebraska [24] and Texas [25], and even at local level [26]. These studies use the JEDI (Jobs and Economic Development) model, a spreadsheet tool that applies standard I-O multipliers and consumption patterns [26], whereas no sub-national level I-O table is utilized. Such analyses highlight the importance of the assumptions about domestic/local shares of intermediate inputs and labor. Coon et al. [27] assess the impact of all the RE sector for North Dakota and combine a state-level Input-Output Table and a survey of businesses, in which in-state expenditures are investigated. Llera-Sastresa et al. [28] develop a methodological approach of the "employment factors" type for the autonomous community of Aragon in Spain. Ulrich et al. [9] developed a model to allocate direct and indirect employment of the RE sector to the to the 16 German states, whereas Heinbach et al. [29] have built a model for estimating the contribution to municipal value added resulting from local RE generation facilities. However, these studies on Germany neglect to account for negative effects. A sub-national net impact assessment was carried out for the deployment of marine energy in Scotland by applying a CGE model calibrated for the Scottish economy [30].

Energy policy could generate contrasting incentives among different administrative levels and possibly conflicts with local communities. Sharing revenue with host communities is crucial for local acceptance [31], and, likewise, the community's involvement in the decision-making process should not be neglected [32]. The energy transition is a complex process with profound implications on spatial organization of energy systems and economic activities both between and within nations [33]. In the 19th century, uneven industrialization and urbanization processes were shaped by access to coal resources, whereas economies of scale and electricity network technologies favored a centralized system of energy generation [33,34]. The transition to a carbon-free energy system must be built upon these existing spatial differences and could be affected from a path dependency that make it difficult to integrate new technologies into the incumbent system [35]. Concentration of RE supply and electricity demand, network constraints, clustering of RE technologies manufacturing and jobs, and rural-urban differences might lead to diverging paths in economic development [34]. Policies to support RET deployment and integration tend to increase household electricity prices. Energy affordability, in addition to the above mentioned regressive effects, may also entail consequences for health outcomes and life satisfaction, especially among low-income households [36]. Furthermore, the governance of energy transitions, and energy systems, in general, is fragmented across many actors and government levels, whereas the allocation of cost and benefits to each actor is very intricate. Where countries such as the UK and USA have devolved a consistent part of RE policies to sub-national government levels [37,38], the German $E E G$ has been one of the most impressive experiments of RE promotion on a national scale.

\section{EEG Mechanisms and the Case of North Rhine-Westphalia}

\subsection{Renewable Energy Resources Act (EEG) in Germany}

The Renewable Energy Sources Act (Erneuerbare-Energien-Gesetz, EEG) was first enacted in 2000, and updated several times (EEG2004, EEG2009, EEG2012, EEG2014, EEG2017). This law aimed at promoting and steering the deployment of renewable energy technologies (RET), by guaranteeing, for 
ca. 20 years, fixed tariffs for electricity from RET, as well as its priority feed-in into the power grid. Such so-called feed-in tariffs (FiTs) vary according to the technology (e.g., photovoltaic, wind), the type (e.g., rooftop-, ground-mounted) and peak capacity of the installation. The law prescribes that such subsidies are financed through a fixed electricity surcharge (i.e., EEG-Umlage) paid by final consumers per each $\mathrm{kWh}$ of electricity used, which amounted to $3.53 \mathrm{ct} / \mathrm{kWh}$ in 2011. Energy-intensive industries can obtain a reduced surcharge, and such an exception is considered in our model.

\subsection{The Case of North Rhine-Westphalia}

This national policy (EEG) might have resulted in an uneven impact on a sub-national level, as a result of the uneven distribution of RE sources and installations, conventional energy power plants, mining activities, and their respective supply chains. North Rhine-Westphalia (NRW) represents an illustrative case of a potential "geographically disruptive" transition, since the old fossil-fuel based energy system is deeply embedded in its territory and economic structure, whereas renewable energy resources are relatively scarce compared to less densely populated regions.

In the analyzed year, NRW represented $21.9 \%$ of German population and $21.8 \%$ of GDP [39]. However, with regard to RET promotion, it received 10.0\% of subsidies (i.e., FiTs), yet its energy consumers paid $25.8 \%$ of national energy surcharge [40,41].

Moreover, with regard to national electricity generation (Figure 1), $45.7 \%$ of electricity from hard coal and $51.1 \%$ from lignite was generated in NRW, in comparison to only $10.6 \%$ of electricity from RE [42]. Finally, the energy intensity of the NRW economy is also above the national average, and in fact ca. $32 \%$ of overall energy consumption by the industrial and mining sector took place in this federal state [43].

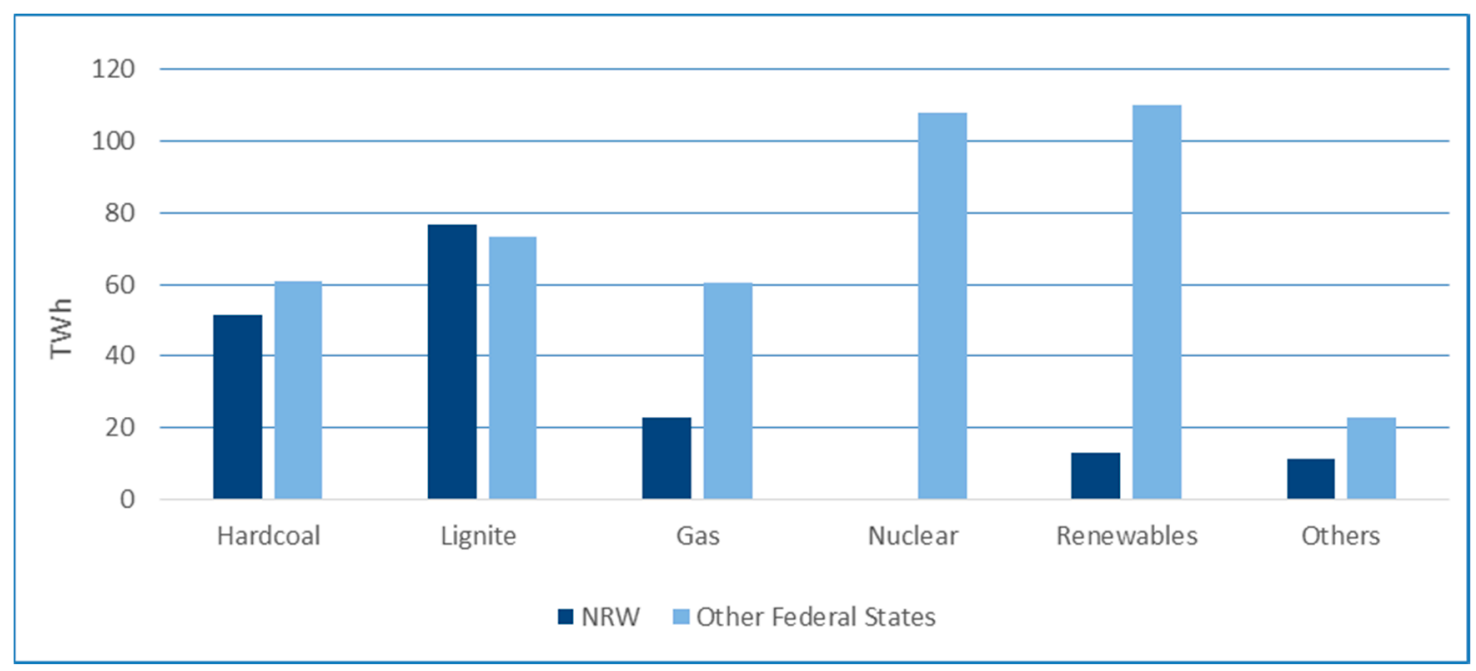

Figure 1. Electricity generation by energy source in 2011, source: own graph based on data from [42].

Given the structure of its economy and energy system, we consider North-Rhine Westphalia an ideal case to study the impact on regional value-added resulting from the national energy transition. Our paper's contribution to the literature is twofold. Firstly, it is one of the few studies, and the only one for Germany, that presents a net impact assessment at a sub-national level. Secondly, to our knowledge, it is the only study (following Többen [8]) that disentangles the regional impact of a national policy, whereas other studies analyze the effect of local deployment of RE on local economies.

\section{Materials and Methods}

In order to combine our ambition for a comprehensive net impact assessment and its feasibility in terms of data, we follow the methodology of Többen [8]. This approach fits the scope of our study, which is a retrospective static assessment for the year 2011. Unlike Többen [8], we concentrate on 
the net impacts on regional value added rather than the distribution of income across households and, therefore, do not model the interrelations between households and industries endogenously. Furthermore, the MRIO (multi-regional input-output) table for German Federal States [44] is ideally suited to assess the regional impact of a nationwide policy (i.e., $E E G$ ).

The analysis will apply an input-output approach (I-O) that includes a quantity model and a price model $[10,45,46]$. The quantity model calculates the change in gross value added that is linked to a change in the demand for goods and services across all supply chains. This deals with what is known as the "demand-pull" effect. In contrast, the price model investigates the effects on the overall price level resulting from a change in the production costs of companies. It works under the assumption that companies will pass on the rise in costs to their consumers through price increases. This kind of development constitutes what is known as a "cost-push" effect.

When analyzing the effects on gross value added (i.e., the sum of wages and salaries, taxes, and profits), a distinction is made between the operation of facilities generating renewables and the production of such facilities in Germany for domestic use and for export abroad. While the operation of such facilities is directly linked to the $E E G$, the effects of manufacturing are only indirectly related to the EEG. The reason for this is that the funding for renewables occurs independently of whether the facility and its components were built in Germany or imported. For the operation and production of facilities generating renewable energy, a distinction can be made between various impact channels (direct effects), which are linked to either expansionary or contractionary (indirect) effects on the value added. As this paper considers both expansionary and contractionary effects, the results can be interpreted as net effects. This contrasts with many input-output analyses which exclusively consider gross effects (e.g., in [47]), which by definition are always positive.

\subsection{Impact Channels Resulting from the Operation of Facilities Generating Renewable Energies}

The value-added effects from the operation of facilities generating renewable energies can be broken down into three impact channels (Figure 2):

- The operation of the facilities results in expansionary effects on aggregate demand and thus also on the value added of companies that satisfy this demand either directly or indirectly (as suppliers of intermediate goods along the value chains). Firstly, demand for maintenance work and replacement parts arises from the operation of facilities generating renewables. In the case of electricity produced from biomass, additional demand is generated by the need for fuels. At the same time, the operation of such facilities generates income, which in turn boosts private consumption and stimulates aggregate demand. This income consists of the wage and salary payments of operators and from the feed-in tariff, less operating and financing costs.

- The financing of the feed-in tariff via the $E E G$ levy leads to contractionary effects on aggregate demand due to its direct and indirect effects on purchasing power and thus also household demand. On the one hand, households lose purchasing power directly through the payments they make, while, on the other hand, they also indirectly bear the costs of the levy on companies. The cost-push effect associated with the increased production costs is determined with the aid of an I-O price model. The reduction in purchasing power has negative effects on private consumption, which in turn results in negative effects on value added. This effect is examined using the I-O quantity model.

- The preferred feed-in of electricity from renewable energy sources leads to a contractionary-acting substitution effect, as electricity from conventional sources is displaced. The analysis works on the assumption that for every $\mathrm{kWh}$ of electricity generated from renewable energy sources, one $\mathrm{kWh}$ of electricity from conventional power plants (i.e., conventional energy technologies, CET) is displaced. This is associated with reduced demand for maintenance, replacement parts, and above all fossil fuels, which in turn leads to a reduction in aggregate demand and thus also value added. At the same time, this also results in a reduced import of fossil fuels. 


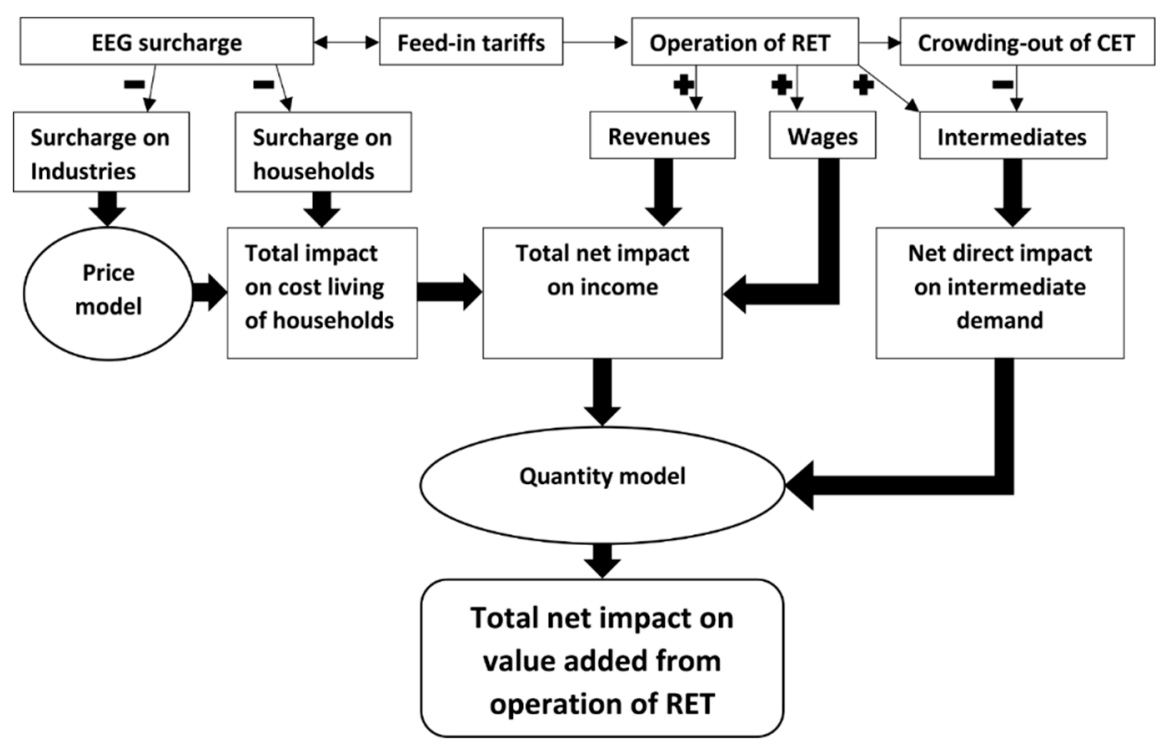

Figure 2. Block diagram of the impact channels resulting from operation of RET within the modeling framework.

\subsection{Impact Channels Resulting from the Production of Facilities Generating Renewable Energies}

The production of facilities generating renewable energies is indirectly linked with the EEG and can be broken down into two impact channels (Figure 3):

- The production of facilities generating renewable energies either for domestic use in Germany or for export abroad leads to expansive effects on aggregate demand and thus also on value added. The two major drivers of these effects are manufacturers' demand for intermediate goods, on the one hand, and the increased demand for consumer goods resulting from wage and salary payments, on the other.

- In the long term, investments in fossil-fired power plants will be displaced (substitution) as a result of investments in renewables, which in turn will lead to a contractionary effect on aggregate demand. The guaranteed capacity of the newly installed renewables will form the basis to indicate the extent to which investments in fossil-fired power plants will be displaced. Investments in technology bundles (renewables vs. fossil fuels) of equal guaranteed capacity will therefore be compared. The contractionary effect on aggregate demand is driven by the reduced demand for intermediary goods, on the one hand, and reduced private consumption resulting from the number of jobs not created in power plants, on the other.

\subsection{The I-O Modeling Approach}

The model used is a multi-regional quantity and price input-output model. The quantity model delivers the economy-wide impacts of an exogenous change in the demand for products and in income levels of households. It can, therefore, be characterized as a demand-pull input-output model [45]. In this model, any change in product demand and income levels is assumed to be the starting point for a cascade of higher-order indirect impacts on industries and households through interindustry linkages and the circular flow of (labor) income and expenditure. Apart from the energy surcharge on industries, all other direct impacts described above are directly fed into the quantity model, in order to estimate total impacts on industries and households. Such direct impacts are exogenous inputs for the I-O modeling, and are estimated either through the use of an enterprise survey or other official statistics (see. Section 4.4).

$$
\Gamma=(\boldsymbol{I}-\mathbf{D B})^{-1}
$$


In Equation (1) the Leontief inverse, $\Gamma$, consists of two components. The matrix product, $D B$, represents interregional interindustry relationships. The intermediate demand coefficients, $\boldsymbol{B}$, are used to determine the change in intermediate input requirements of regional industries due to an exogenous change in the demand for their products, while industry market shares, $D$, translate these product-requirements into demand directed to industries. Here, $b_{j i}^{r s} \in \boldsymbol{B}$ denotes intermediate demand for product $j$ from region $\mathrm{r}$ per unit of output of industry $i$ from region s and $d_{i j}^{r} \in \boldsymbol{D}$ denotes the market share of industry $i$ in the total supply of product $j$ by region $r$.

$$
\begin{gathered}
\Delta v a=\omega \Gamma D[\Delta u ; \Delta f] \\
\Delta v a=\omega \Gamma D C[\Delta r ; \Delta w ; \Delta v]
\end{gathered}
$$

Equation (2) gives the indirect impact on value added due to the direct impact on intermediate demand from the renewable and conventional energy sectors. $\Delta u$ is the exogenous direct impact on intermediate demand resulting both from the promoted operation of RET (positive effect), as well the crowded-out operation of conventional energy facilities (negative effect). Similarly, $\Delta f$ is direct impact on intermediate demand resulting both from the promoted production of RET and the crowded-out investments in new conventional power plant capacity. Since the extended Leontief inverse delivers total impacts on gross output of industries rather than on value added, $v \boldsymbol{a}$, it is pre-multiplied by exogenous value added per unit of output coefficients $\omega$.

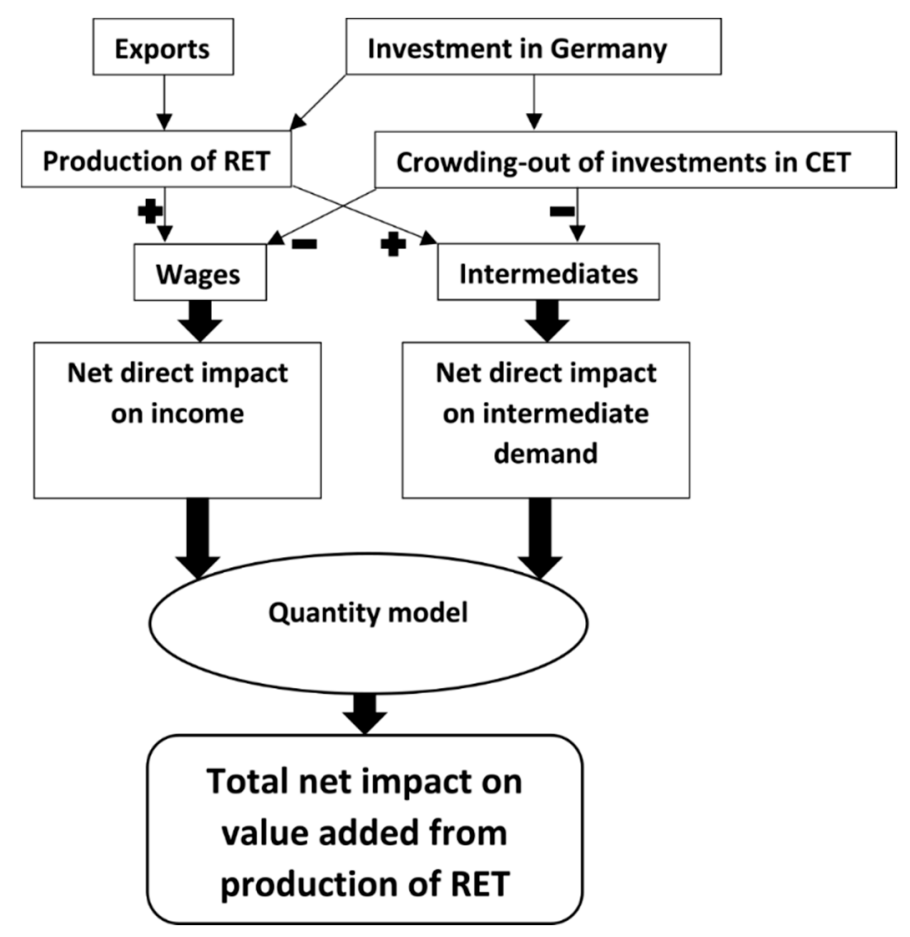

Figure 3. Block diagram of the impact channels resulting from production of RET within the modeling framework.

Equation (3) gives the induced impact on value added, resulting from an exogenous change in the income of households, here the Leontief inverse is post-multiplied by $D C$, where $C$ delivers the corresponding private consumption expenditures, which are directed to industries. $\Delta r$ contains the additional income from the revenues of feed-in tariffs going to private households (direct impact), as well as the sub-vector $\Delta r_{\text {sur }}$ which indicates the negative total impact resulting from higher living cost due to the energy surcharge. This includes both, the direct increase of the cost of living due to the increase of household's electricity prices, as well as the indirect losses due to increased electricity prices faced by companies passed on to households, which result from the price model (see below). 
$\Delta w$ is the direct impact resulting both from additional labor income paid for the operation of RET, as well as the crowded-out labor income resulting from reduced operation of conventional energy facilities. Finally, $\Delta v$ denotes the corresponding variation of labor income in the case of production of RET facilities and crowding-out of investments in new conventional power plant capacity.

The price model delivers the cost-push effect of the direct impact of an exogenous increase in input prices on the price of final goods, and hence on the cost of living of households $\left(\gamma_{h}\right)$. It is assumed that industries pass on the increased production costs.

$$
\Delta \gamma_{h}=\Gamma^{\prime}\left(\Delta \tau_{\mathbf{i}} \delta_{\mathbf{i}}\right) D C
$$

Equation (4) delivers the indirect impact of an exogenous increase in electricity prices for industries (i.e., electricity surcharge, including reduced surcharge for energy-intensive industries) on the cost of living of households $\left(\gamma_{h}\right)$. This involves the multi-regional Leontief inverse, $\Gamma$, which comprises price effects rippling through the network of interregional supply chains, represented by $D B . \Delta \tau_{i} \delta_{i}$ denotes the exogenous shock, namely the percentage change in the costs of production of industries, where $\Delta \tau_{i}$ represents the relative change in electricity prices due to the surcharge and $\delta_{i}$ the fixed electricity inputs per unit of gross output. In order to estimate such direct impact, $\Gamma$ is post-multiplied by $\left(\Delta \tau_{i} \delta_{i}\right) D C$, where market shares, $D$, deliver the average price increase of a certain product from a certain region, which is further translated into the associated increase in the costs of living via consumption coefficients, $C$.

\subsection{Data}

A detailed description of the data for the construction of the MRIO of the German federal states is given in Többen [44]. The MRIO is based on a hybrid approach [48], where, at first, the non-survey method CHARM [49] is used to construct a prior table which delivers a basic representation of the table's structure and initial estimates of its elements. Afterwards, the quality of this prior is improved through the integration of survey-based information on table elements of particular importance for this study by means of the KRAS algorithm [50,51]. The approach taken here can be justified by the concept of holistic accuracy developed by Jensen [52], who found that the results of I-O models are driven by only a few large table elements. Regional income and consumption patterns are estimated from household level micro data from the income and expenditure survey (Einkommens-und Verbrauchsstichprobe, EVS), whereas input structures of industries are based on firm-level microdata from the German costs structure survey. Both datasets were provided by the federal statistical office. Finally, interregional trade flows between the federal states are estimated from freight transportation data.

For an analysis of the demand-pull effects, it is particularly important to have precise data about the cost structures of the manufacturers and operators of facilities [53]. This paper applies information from a corporate survey, with technology- and region-specific data on intermediate demand, import shares, gross output, and value added as residual. These survey data have been used in numerous studies on the overall economic effects of renewables $[6-9,15,47]$. Data on FiTs payment, divided according to federal state and technology, are provided by BDEW. These represent the gross output of $\mathrm{RE}$ sector, from which labor and intermediate inputs are derived. As a proxy for labor compensation for the production and operation of RE technologies, shares of labor sectors from comparable sectors were used (e.g., electrical equipment and machinery industry). EVS were used to estimate the impact of FiTs and labor income, as well as the electricity surcharge on available income and consumption of households.

For the estimation of the cost-push effect from industries, it is necessary to estimate the direct effect of the surcharge on the costs of production. For this, the payments of households are subtracted from total regional surcharge payments, which delivers total payments by all industries in a region. For the allocation of this remainder across regional industries, this is carried out separately for energy-intensive industries, which pay a drastically reduced surcharge ( $0.05 \mathrm{ct}$ for each $\mathrm{kWh}$ exceeding $10 \mathrm{GWh})$, and 
the remaining industries that pay the normal surcharge of $3.53 \mathrm{ct} / \mathrm{kWh}$. The amount of electricity to which the reduced surcharge applies is provided by the Federal Office of Economics and Export Control (BAFA) for industries at the national level and regional totals. The estimation of the privileged electricity (electricity to which a reduced EEG surcharge applies) by regional industries assumes that the ratios of privileged to total electricity at the national and the regional level are equal, in a first step. In the second step, these estimates are adjusted to regional totals and the national values by industry using the RAS method. These estimates are then used to split total electricity consumption of regional industries provided by the federal statistical office into the amount of electricity to which the reduced surcharge applies and that amount to which the normal surcharge applies. Multiplying both by the respective surcharge and dividing the resulting monetary value of surcharge payments by an industry's gross output delivers, finally, the direct percentage increase in the cost of production.

A detailed description of data sources, assumptions to derive the exogenous direct impacts, as well as a detailed discussion of the price and quantity input-output models can be found in the SI of Többen [8].

\section{Results}

Firstly, the value-added effects associated with the operation and production of facilities generating renewable energies in NRW and the remaining federal states will be considered. The effects on the NRW economy will then be broken down and examined according to sectors.

Figure 4 demonstrates the nationwide value-added effects resulting from the operation of facilities generating renewables in millions of euros (yellow dots), as well as the percentage shares of North Rhine-Westphalia and the remaining federal states. It reveals how the operation of such facilities in 2011 led to an overall loss of value added of roughly $€ 2.35$ billion. While the operation of facilities (impact channel 1) is associated with a nationwide expansive effect amounting to roughly $€ 3$ billion, this is more strongly offset by the reduction in purchasing power, which is directly and indirectly linked to the financing of the feed-in tariff via the EEG levy (impact channel 2). The reduction in purchasing power amounts to a loss of value added of around $€ 4.6$ billion across Germany. In comparison, the contractionary substitution effect resulting from the preferred feed-in of electricity generated from renewable energy sources (impact channel 3) carries considerably less weight at a total of around $€ 750$ million.

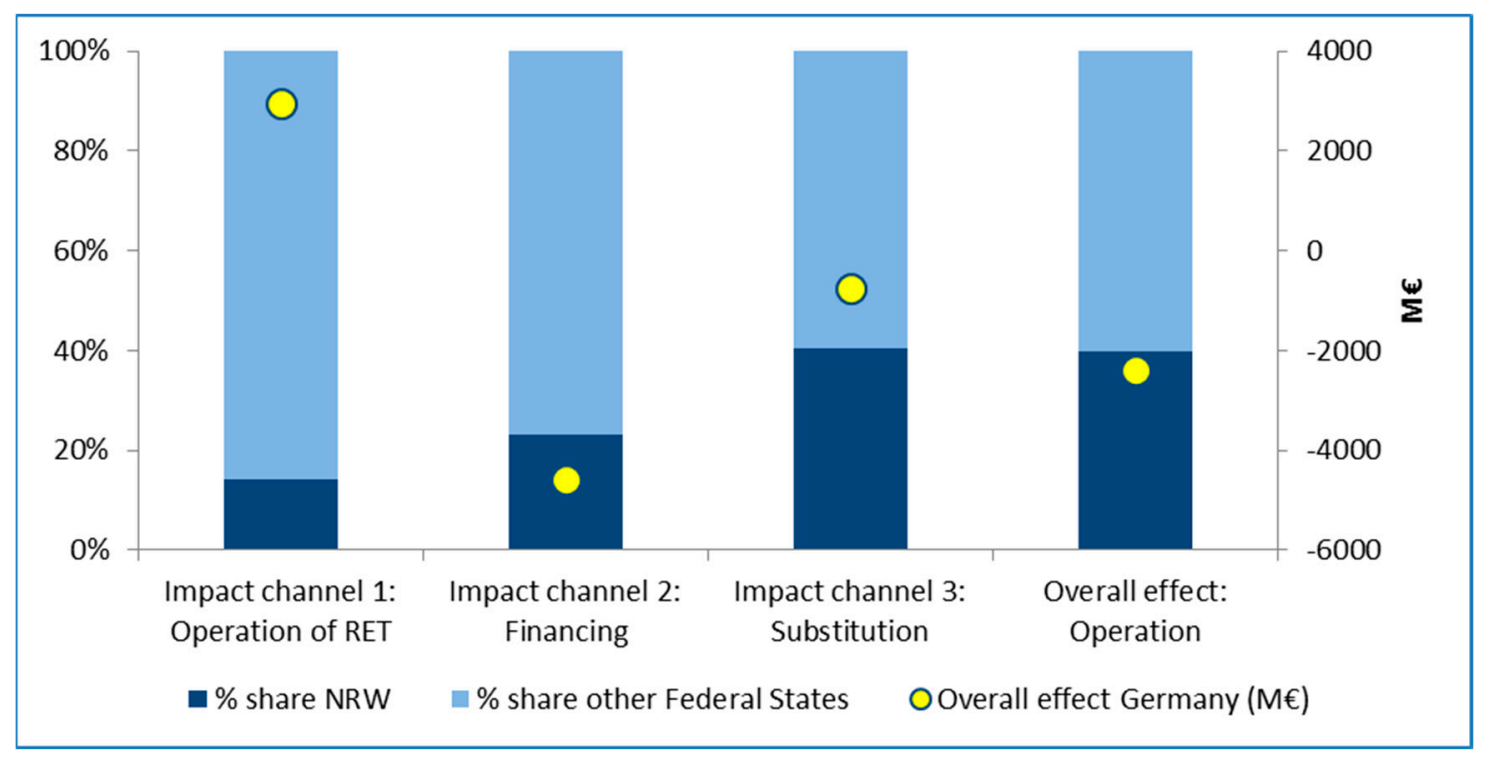

Figure 4. Value-added effects (in million $€$ ) of impact channels resulting from the operation of RET at national and state level (right $y$-axis) and respective sub-national shares (left $y$-axis). 
With respect to the allocation of these effects among the German federal states, it can be determined that around $40 \%$ of the overall negative effect is attributed to North Rhine-Westphalia. In relation to the state's shares of overall German GDP and the entire German population (roughly 21\%), North Rhine-Westphalia is thus affected in a considerably disproportionate manner. This result can be traced back to the fact that NRW's share of expansive effects from the operation of such facilities is very low (roughly 14\%) in relation to the size of the federal state, whilst its shares of contractionary effects through financing are slightly disproportionate (23\%) and those resulting from substitution considerably disproportionate (41\%). The main reasons behind this include the relatively low installed capacity of renewable energy facilities in North Rhine-Westphalia, as well as the NRW economy's strong focus on energy-intensive sectors and the generation of electricity from lignite and hard coal.

Figure 5 depicts the nationwide value-added effects from the production of facilities generating renewable energies in the millions of euros (yellow dots), as well as the percentage shares of North Rhine-Westphalia and the remaining federal states. It reveals that the overall effect is a very positive one at roughly $€ 9.4$ billion, and thus considerably outweighs the negative overall value-added effect from the operation of the facilities. The main drivers of this result are the high increase in aggregate demand as a result of domestic investments, as well as export demand (impact channel 4). The nationwide value-added effect of this demand amounts to roughly $€ 9.9$ billion. In comparison, the contractionary effect resulting from the displacement of investments in fossil-fired power plants is rather minor at roughly $€ 500$ million. The relatively minor effects from impact channel 5 can be predominantly explained by the considerably lower installed capacity of fossil-fired power plants that is required for supplying $1 \mathrm{kWh}$ of guaranteed capacity.

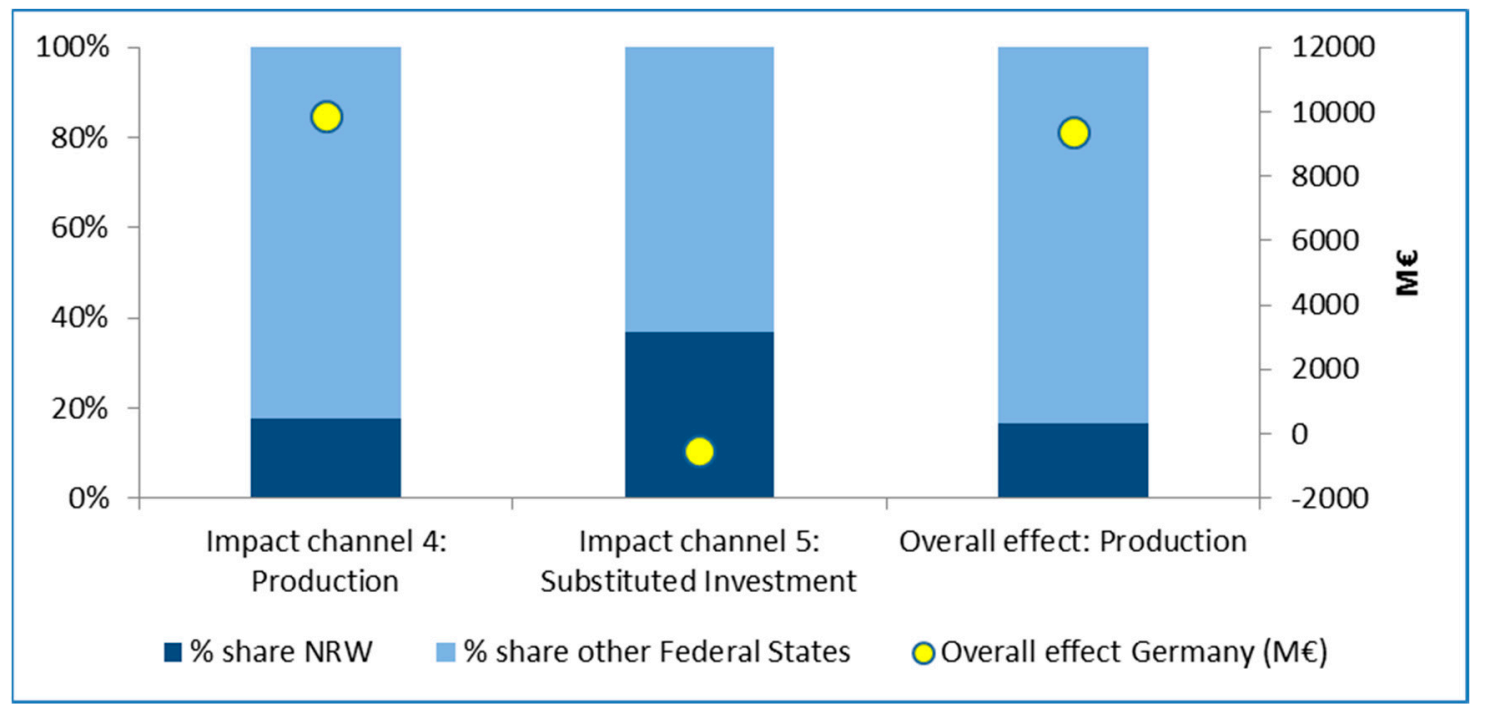

Figure 5. Value-added effects (in million $€$ ) of impact channels resulting from the production of RET at national and state level (right $y$-axis) and respective sub-national shares (left $y$-axis).

Similar to the operation of facilities generating renewables, it can be seen from the production of such facilities that NRW's benefits from the expansive effects on value added are disproportionally low, whilst the state is also affected disproportionately strongly by the contractionary effects. NRW accounts for roughly $18 \%$ of the expansive effect resulting from production, but also $37 \%$ of the contractionary effect through the displacement of investments. However, the overall effect for NRW remains a positive one amounting to roughly $€ 1.55$ billion-corresponding to roughly $17 \%$ of the nationwide effect-due to the comparatively small size of the contractionary effect. If the overall effects from operation and production are added together (Figure 6), an overall positive effect amounting to roughly $€ 7$ billion can be seen for both North Rhine-Westphalia and the remaining federal states. However, NRW's share of this effect (roughly $9 \%$ ) is very low when considering the size of the federal state. 


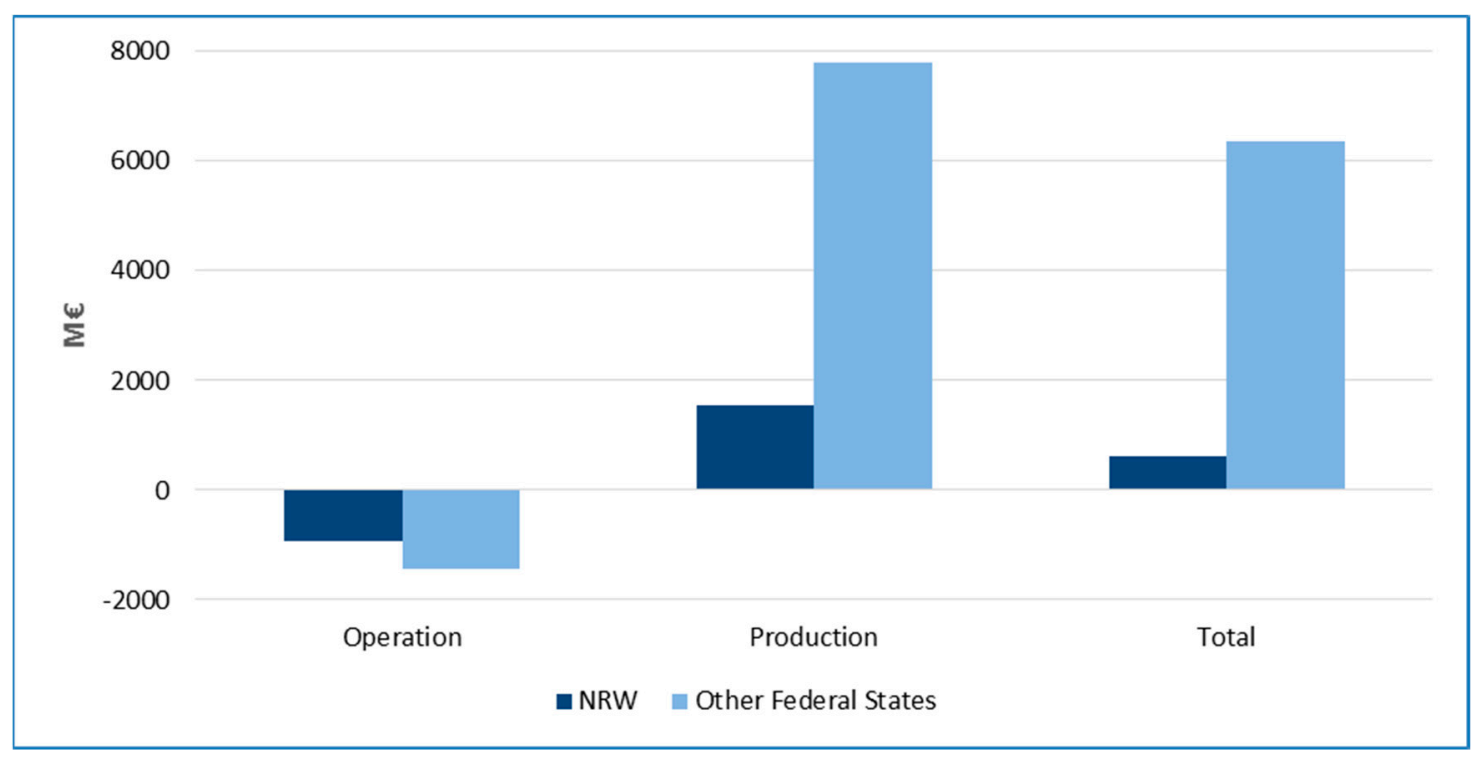

Figure 6. Overall value-added effects (in million $€$ ) from production and operation of RET.

The allocation of the overall effects from production and operation across the various sectors in North Rhine-Westphalia can be seen in Figure 7.

With respect to the production of facilities generating renewable energies, it is clear that there are no negative effects on value added observed in any of the industrial sectors. Especially in the processing trade, companies from the metal working sector, electronics industry, and mechanical engineering sector are able to profit. In addition, the business-related services sector and construction industry in particular continue to profit highly. These sectors are particularly closely integrated along supply chains in the production, installation, planning, and project development of renewable energy facilities. More than half of the value-added effects can be traced back to manufacturers in other federal states that are highly dependent on the supply of intermediate goods from NRW.

In contrast, the allocation of overall effects from the operation of facilities generating renewable energies reveals a considerably different picture. Firstly, positive effects are only observed in three of the sectors investigated-namely the agricultural sector, metal fabrication and electronics industry which benefit, in particular, from the supply of biomass and replacement parts. All other sectors, however, reveal negative value-added effects. Secondly, the overall effects are concentrated much more strongly on the services sectors, particularly housing, retail, hotel and catering, and other personal services. This effect is brought about in particular by the reduction of purchasing power resulting from the EEG levy. Heavy value-added losses continue to be observed in the mining industry, which can be traced back to the substitution effect. 


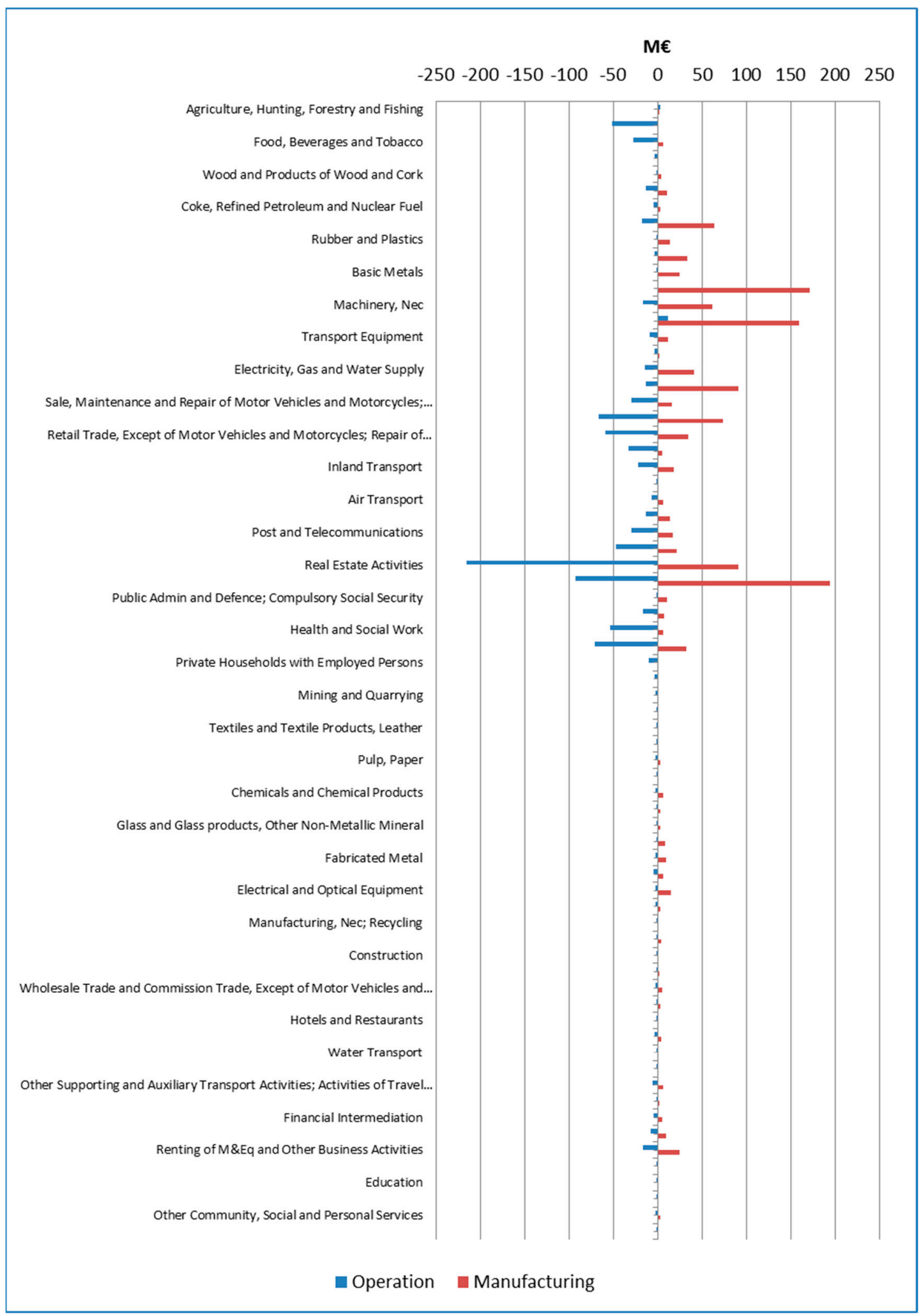

Figure 7. Sector-allocation of overall effects from the operation and production of RET across the NRW economy.

\section{Discussion}

Overall, the analysis of the value-added effects in North Rhine-Westphalia, resulting from the funding, operation, and production of renewable energy facilities in 2011, produces a mixed result. 
Strong contractionary effects are observed in particular through the financing of the feed-in tariff via the EEG levy. These effects are the result of the reduction in purchasing power of private households and have a particularly negative effect on the producers of consumer goods and the providers of private services. In contrast, very positive value-added effects are created by the production of facilities for domestic use and for export. In comparison with the other federal states, NRW profits only to a relatively low degree from the positive effects, while it is also disproportionally affected by the negative effects. By 2015 NRW still received only 10\% (as in 2011) of EEG subsidies inflows [54], despite its share of population (ca. one fifth) and electricity consumption (ca. one fourth), hence we consider it to be crucial, for a regionally uniform energy transition, that such a state increases its national share of RET deployment. When comparing per capita RET installations, NRW falls behind states with similar or worse RES conditions, e.g., per capita PV installations in Lower Saxony or Schleswig-Holstein are higher than in NRW. For this reason, we think there might be the need to further identify and address behavioral, social, and technical barriers in NRW, in order to overcome RET investment hurdles.

When evaluating the findings, it is important to consider that the positive effects from the production of renewable energy facilities are one-off effects. The overall negative effects from the operation of the facilities, however, occur throughout their entire lifespan. Furthermore, the year 2011 constitutes an exceptional one, as the second-highest level of investments in new facilities in Germany to date was recorded during that year and the $E E G$ levy was considerably lower than is currently the case (3.53 ct/kWh in 2011 against $6.792 \mathrm{ct} / \mathrm{kWh}$ in 2018). Although we point out the enduring negative economic impact for NRW, our aim is not to criticize the deployment of RET in its own right, but to stress the fact that such uneven regional and sectoral impact should be addressed by policy makers, in order to ease the energy transition and its public support. Finally, within this analysis, we do not consider the potential ancillary benefits of de-carbonization in NRW (e.g., for health and environmental outcomes), which would counterbalance the discussed monetary downsides.

Recently, the EEG introduced new financing procedures for large RE sites, focusing on bidding processes. For several projects, this approach resulted in a drastically lower RE financing costs compared to FiTs. On the other hand, direct employment in RE sector, which accounted for 400,000 jobs in 2012, went down by ca. 11\% between 2012 and 2014. In particular, in the PV sector, jobs plummeted from 100,300 to 38,300 over this period [55,56] and new data on cost structure could scale down the positive multiplier effects of RET production. Moreover, our analysis cannot embrace the whole technical complexity of the electricity market, especially with regard to spatial and temporal generation and load, as well as grid constraints. For example, merit order effect, induced by RE, drives down the wholesale price of electricity and may favor energy-intensive industries. On the other hand, RET deployment entails additional costs for the network operators (grid expansion, power curtailment, re-dispatch, etc.), such costs are passed to final customers and are not covered by the EEG-Umlage. Therefore, it is preferable to conduct further studies on the regional economic impact of RE policies on the federal state level which can overcome such limitations.

Author Contributions: Conceptualization, J.T.; methodology, J.T.; formal analysis, J.T.; writing-original draft preparation, G.A., J.T. and W.K.; writing—review and editing, G.A., J.T. and W.K.; supervision, W.K.

Funding: The study was funded by the foundation Stiftung Mercator.

Acknowledgments: The studies were compiled within the framework of the Virtual Institute (VI) "Transformation-Energy Transition NRW" (http://www.vi-transformation.de/en/). We would like to thank the foundation Stiftung Mercator for its support.

Conflicts of Interest: The authors declare no conflict of interest. The funders had no role in the design of the study; in the collection, analyses, or interpretation of data; in the writing of the manuscript, or in the decision to publish the results.

\section{References}

1. Blyth, W.; Gross, R.; Speirs, J.; Sorrell, S.; Nicholls, J.; Dorgan, A.; Hughes, N. Low Carbon Jobs: The Evidence for Net Job Creation from Policy Support for Energy Efficiency and Renewable Energy; UKERC: London, UK, 2014. 
2. Breitschopf, B.; Nathani, C.; Resch, G. Review of Approaches for Employment Impact Assessment of Renewable Energy Deployment. EID (Economic and Industrial Development)-EMPLOY, Final Report-Task. 2011, p. 101. Available online: http://publica.fraunhofer.de/dokumente/N-198802.html (accessed on 9 September 2019).

3. Cameron, L.; Van Der Zwaan, B. Employment factors for wind and solar energy technologies: A literature review. Renew. Sustain. Energy Rev. 2015, 45, 160-172. [CrossRef]

4. Fischer, W.; Hake, J.F.; Kuckshinrichs, W.; Schröder, T.; Venghaus, S. Five controversial issues in the debate on the German 'Energiewende'. Energy 2016, 115, 1580-1591. [CrossRef]

5. Frondel, M.; Ritter, N.; Schmidt, C.M.; Vance, C. Economic impacts from the promotion of renewable energy technologies: The German experience. Energy Policy 2010, 38, 4048-4056. [CrossRef]

6. Lehr, U.; Lutz, C.; Edler, D. Green jobs? Economic impacts of renewable energy in Germany. Energy Policy 2012, 47, 358-364. [CrossRef]

7. Lehr, U.; Nitsch, J.; Kratzat, M.; Lutz, C.; Edler, D. Renewable energy and employment in Germany. Energy Policy 2008, 36, 108-117. [CrossRef]

8. Többen, J. Regional net impacts and social distribution effects of promoting renewable energies in Germany. Ecol. Econ. 2017, 135, 195-208. [CrossRef]

9. Ulrich, P.; Distelkamp, M.; Lehr, U. Employment effects of renewable energy expansion on a regional level first results of a model-based approach for Germany. Sustainability 2012, 4, 227-243. [CrossRef]

10. Miller, R.; Blair, P. Input-Output-Analysis: Foundation and Extension; Cambridge Press: New York, NY, USA, 2009.

11. Pfaffenberger, W.; Nguyen, K.; Gabriel, J. Ermittlung der Arbeitsplätze und Beschäftigungswirkungen im Bereich Erneuerbarer Energien; Studie des Bremer Energie Instituts im Auftrag der Hans-Böckler-Stiftung: Bremen, Germany, 2003.

12. Fahl, U.; Küster, R.; Ellersdorfer, I. Jobmotor Ökostrom?: Beschäftigungseffekte der Förderung von erneuerbaren Energien in Deutschland. ET. Energ. Tagesfr. 2005, 55, 476-481.

13. Hillebrand, B.; Buttermann, H.G.; Behringer, J.M.; Bleuel, M. The expansion of renewable energies and employment effects in Germany. Energy Policy 2006, 34, 3484-3494. [CrossRef]

14. Pfaffenberger, W.; Jahn, K.; Djourdjin, M. Renewable Energies-Environmental Benefits, Economic Growth and Job Creation; Bremer Energie Institut: Bremen, Germany, 2006.

15. Lehr, U.; Lutz, C.; Edler, D.; O’Sullivan, M.; Nienhaus, K.; Nitsch, J.; Breitschopf, B.; Bickel, P.; Ottmüller, M. Kurz- und Langfristige Auswirkungen des Ausbaus der Erneuerbaren ENERGIEN auf den Deutschen Arbeitsmarkt; BMU: Berlin, Osnabrück, Germany, 2011.

16. Blazejczak, J.; Braun, F.G.; Edler, D.; Schill, W.P. Economic effects of renewable energy expansion: A modelbased analysis for Germany. Renew. Sustain. Energy Rev. 2014, 40, 1070-1080. [CrossRef]

17. Andor, M.; Frondel, M.; Vance, C. Germany's Energiewende: A Tale of Increasing Costs and Decreasing Willingness-to-Pay. Energy Jornal 2017, 38, 211-228.

18. Böhringer, C.; Keller, A. Van der Werf, E. Are green hopes too rosy? Employment and welfare impacts of renewable energy promotion. Energy Econ. 2013, 36, 277-285. [CrossRef]

19. Böhringer, C.; Landis, F.; Reanos, M.A.T. Economic Impacts of Renewable Energy Promotion in Germany. Energy J. 2017, 38.

20. Frondel, M.; Sommer, S.; Vance, C. The burden of Germany's energy transition: An empirical analysis of distributional effects. Econ. Anal. Policy 2015, 45, 89-99. [CrossRef]

21. Meyer, I.; Sommer, M.W. Employment Effects of Renewable Energy Deployment-A review. Int. J. Sustain. Dev. 2016, 19, 217-245. [CrossRef]

22. Cai, M.; Cusumano, N.; Lorenzoni, A.; Pontoni, F. A comprehensive ex-post assessment of RES deployment in Italy: Jobs, value added and import leakages. Energy Policy 2017, 110, 234-245. [CrossRef]

23. Ortega, M.; del Río, P.; Ruiz, P.; Thiel, C. Employment effects of renewable electricity deployment. A novel methodology. Energy 2015, 91, 940-951. [CrossRef]

24. Lantz, E. Economic Development Benefits from Wind Energy in Nebraska: A Report for the Nebraska Energy Office (Revised); National Renewable Energy Laboratory (NREL): Golden, CO, USA, 2009.

25. Reategui, S.; Hendrickson, S. Economic Development Impact of 1000 MW of Wind Energy in Texas; National Renewable Energy Laboratory (NREL): Golden, CO, USA, 2011. 
26. Slattery, M.C.; Lantz, E.; Johnson, B.L. State and local economic impacts from wind energy projects: Texas case study. Energy Policy 2011, 39, 7930-7940. [CrossRef]

27. Coon, R.C.; Hodur, N.M.; Bangsund, D.A. Renewable Energy Industries' Contribution to the North Dakota Economy; Agribusiness \& Applied Economics Report 702; Department of Agribusiness and Applied Economics, North Dakota State University: Fargo, ND, USA, 2012. [CrossRef]

28. Llera Sastresa, E.; Usón, A.A.; Bribián, I.Z.; Scarpellini, S. Local impact of renewables on employment: Assessment methodology and case study. Renew. Sustain. Energy Rev. 2010, 14, 679-690. [CrossRef]

29. Heinbach, K.; Aretz, A.; Hirschl, B.; Prahl, A.; Salecki, S. Renewable energies and their impact on local value added and employment. Energy Sustain. Soc. 2014, 4, 1. [CrossRef]

30. Gilmartin, M.; Allan, G. Regional Employment Impacts of Marine Energy in the Scottish Economy: A General Equilibrium Approach. Reg. Stud. 2015, 49, 337-355. [CrossRef]

31. Allan, G.; Mcgregor, P.; Swales, K. The importance of revenue sharing for the local economic impacts of a renewable energy project: A social accounting matrix approach. Reg. Stud. 2011, 45, 1171-1186. [CrossRef]

32. Cowell, R.; Bristow, G.; Munday, M. Acceptance, acceptability and environmental justice: The role of community benefits in wind energy development. J. Environ. Plan. Manag. 2011, 54, 539-557. [CrossRef]

33. Bridge, G.; Bouzarovski, S.; Bradshaw, M.; Eyre, N. Geographies of energy transition: Space, place and the low-carbon economy. Energy Policy 2013, 53, 331-340. [CrossRef]

34. Balta-Ozkan, N.; Watson, T.; Mocca, E. Spatially uneven development and low carbon transitions: Insights from urban and regional planning. Energy Policy 2015, 85, 500-510. [CrossRef]

35. Goldthau, A.; Sovacool, B.K. The uniqueness of the energy security, justice, and governance problem. Energy Policy 2012, 41, 232-240. [CrossRef]

36. Chapman, A.; Fujii, H.; Managi, S. Multinational life satisfaction, perceived inequality and energy affordability. Nat. Sustain. 2019, 2, 508-514. [CrossRef]

37. Rabe, B. Contested federalism and American climate policy. Publius J. Fed. 2011, 41, 494-521. [CrossRef]

38. Cowell, R.; Ellis, G.; Sherry-Brennan, F.; Strachan, P.A.; Toke, D. Energy transitions, sub-national government and regime flexibility: How has devolution in the United Kingdom affected renewable energy development? Energy Res. Soc. Sci. 2017, 23, 169-181. [CrossRef]

39. VGRdL. Bruttoinlandsprodukt, Bruttowertschöpfung in den Ländern der Bundesrepublik Deutschland 1991 bis 2017 Reihe 1, Länderergebnisse Band 1; Arbeitskreis "Volkswirtschaftliche Gesamtrechnungen der Länder" im Auftrag der Statistischen Ämter der 16 Bundesländer, des Statistischen Bundesamtes und des Bürgeramtes, Statistik und Wahlen: Frankfurt, Germany, 2015.

40. BDEW. Erneuerbare Energien und das EEG: Zahlen, Fakten, Grafiken (2013); BDEW Bundesverband der Energieund Wasserwirtschaft e.V.: Berlin, Germany, 2013.

41. BDEW. Erneuerbare Energien und das EEG: Zahlen, Fakten, Grafiken (2011); BDEW Bundesverband der Energie-und Wasserwirtschaft e.V.: Berlin, Germany, 2011.

42. LAK-Energiebilanzen. Bruttostromerzeugung nach Energieträgern in GWh (Stand 24.10.18); LAK-Energiebilanzen: Bremen, Germany, 2018.

43. LAK-Energiebilanzen. Endenergieverbrauch nach Verbrauchergruppen in Terajoule (Stand 24.10.18); LAK-Energiebilanzen: Bremen, Germany, 2018.

44. Többen, J. Construction of subnational multiregional Input-Output tables: The case of Germany's federal states. In Proceedings of the 22nd International Input-Output Conference, Lisbon, Portugal, 15-18 July 2014.

45. Oosterhaven, J. Leontieff versus Goshian price and quantity models. South. Econ. J. 1996, 62, 750-759. [CrossRef]

46. Polenske, K.R. Energy analysis and the determination of multiregional prices. Pap. Reg. Sci. 1979, 43, 83-97. [CrossRef]

47. Lehr, U.; Ulrich, P. Erneuerbar Beschäftigt in den Bundesländern: Bericht zur Aktualisierten Abschätzung der Bruttobeschäftigung 2013 in den Bundesländern; BMWi: Berlin, Osnabrück, Germany, 2014.

48. Lahr, M.L. A review of the literature supporting the hybrid approach to constructing regional input-output models. Econ. Syst. Res. 1993, 5, 277-293. [CrossRef]

49. Többen, J.; Kronenberg, T.H. Construction of multi-regional input-output tables using the CHARM method. Econ. Syst. Res. 2015, 27, 487-507. [CrossRef]

50. Lenzen, M.; Gallego, B.; Wood, R. Matrix balancing under conflicting information. Econ. Syst. Res. 2009, 21, 23-44. [CrossRef] 
51. Lenzen, M.; Geschke, A.; Wiedmann, T.; Lane, J.; Anderson, N.; Baynes, T.; Boland, J.; Daniels, P.; Dey, C.; Fry, J.; et al. Compiling and using input-output frameworks through collaborative virtual laboratories. Sci. Total Environ. 2014, 485, 241-251. [CrossRef] [PubMed]

52. Jensen, R.C. The concept of accuracy in regional input-output models. Int. Reg. Sci. Rev. 1980, 5, $139-154$. [CrossRef]

53. Oosterhaven, J.; Van der Kniff, E.C.; Eding, G.J. Estimating interregional economic impacts: An evaluation of non-survey, semi-survey, and full-survey methods. Environ. Plan. A 2003, 35, 5-18. [CrossRef]

54. BDEW. Erneuerbare Energien und das EEG: Zahlen, Fakten, Grafiken (2017); BDEW Bundesverband der Energieund Wasserwirtschaft e.V.: Berlin, Germany, 2017.

55. O'Sullivan, M.; Lehr, U.; Edler, D. Gross Employment from Renewable Energy in Germany in 2013; BMWi: Berlin, Germany, 2014.

56. O'Sullivan, M.; Edler, D.; Lehr, U. Bruttobeschäftigung durch Erneuerbare Energien in Deutschland und Verringerte Fossile Brennstoffimporte durch Erneuerbare Energien und Energieeffizienz; BMWi: Berlin, Germany, 2015.

(C) 2019 by the authors. Licensee MDPI, Basel, Switzerland. This article is an open access article distributed under the terms and conditions of the Creative Commons Attribution (CC BY) license (http://creativecommons.org/licenses/by/4.0/). 